\title{
Microfinance banks and growth of micro, small and medium enterprises in emerging economies: Evidence from Nigeria
}

\author{
Israel S. Akinadewo \\ Department of Management \& Accounting \\ Obafemi Awolowo University, Ile-Ife, Osun State, Nigeria
}

\author{
Keywords \\ Entrepreneurs, expected target, Funding, Microfinance banks, MSMEs
}

\begin{abstract}
This study examined the nexus between microfinance banks and the growth of micro, small and medium enterprises in Nigeria. Research design method through a self-administered questionnaire to respondents was adopted for the study. The respondents comprise the microfinance banks' management and staff and micro, small and medium business entrepreneurs, in Lagos State, the commercial hub of Nigeria. The targeted population of this study was 250 with 223 validly responded. The study tested two hypotheses using logit regression analysis. The hypothesis one shows that the null hypothesis is rejected with the acceptance of the alternate that the microfinance banks in Nigeria channelled their resources to the intended target ( $\mathrm{t}$-calculated of 8.181 is greater than $\mathrm{t}$-tabulated of 0.000 at $5 \%$ level of significance). The findings further showed that a significant positive relationship exists between microfinance banks, proxied by Small Scale Financial Services (SSFS); Financial Sustainability (FST); Absence of Assets-based Collateral (AAC); and Advisory Services (ADS) and the growth of micro, small and medium enterprises in Nigeria. This implies that any upward movement in the services of microfinance banks will enhance the growth of MSMEs. This is further affirmed with the $t$-calculated of $6.540>\mathrm{t}$-tabulated of 0.000 at $5 \%$ level of significance. Thus, rejecting the null hypothesis two and accepting that there is significant positive link between microfinance banks and MSMEs in Nigeria. This study then recommended among others, the need for government to put in place, a strong and more effective team comprises of all stakeholders, to ensure that the microfinance banks do not derail from their primary responsibility of sustaining funding for the MSMEs.
\end{abstract}

\section{Introduction}

In the global economies, Micro, Small, and Medium Enterprises (MSMEs) are pivotal to poverty alleviation, entrepreneurial development, and financial inclusion strategies of governments. Studies also showed that the contributions of MSMEs to nations' economic growth have been universally recognised (Asor et al, 2016; Obasi et al, 2014). In Nigeria, however, the inability of the MSMEs to adequately access working capital loans to grow and expand the respective businesses through the conventional banking/deposit money banks/commercial banks stimulated the establishment of microfinance banks to bridge the existing lacuna. Similarly, the inadequacy of MSMEs promoters' equity contributions and low working capital, which constraints productive capacities, have also led to the early demise and high mortality rate of MSMEs (Khan, 2020; Akingunola et al, 2018). This lack of adequate finance is seen as the major cause of the relative absence of these enterprises in the poor economies (Alalade et al, 2013). Consequent upon this, the emergence of microfinance banks was to assuage the financial incapability of the MSMEs and to encourage enterprises capacity development. Thus, due to the inability of government across the globe to adequately assist the poor on poverty-alleviation, the discovery of microfinance, however, became valuable for the low-income class to access credit and other financial services (Ailemen et al, 2016).

Despite the importance of microfinance banks in the enhancement of the development of MSMEs in Nigeria, Khan (2020) opined that little entrepreneurs patronise these banks. According to this scholar, the militating factors for this are interest rate and strict borrowing conditions, among others. In the opinion of Alalade et al. (2013), finance remains a strategic resource for MSMEs development because investments are needed for new ideas to become marketable products and services. Accordingly, the inability of the MSMEs, to adequately have access to funding from the MFBs is a major retardation to the planned 
economic growth. This assertion by Khan (2020) therefore, has generated a concern among stakeholders and scholars of the need to assess the extent at which the funds available to microfinance banks were channelled to the expected target. Subsequent to this, the microfinance objective includes to assist in the development drive of micro, small, and medium enterprises, to support a sustained economic growth, and to provide loans to micro entrepreneurs to invest in their businesses and grow out of poverty (Abubakar et al., 2015; Ailemen et al., 2016; Asor et al., 2016; Alalade et al., 2013; Khan, 2020; Obasi et al., 2014; Haider et al., 2018; Akande and Yinus, 2015; Moruf, 2013; Dutse et al., 2013; Ede and Elikwu, 2018; Werigbelegha et al., 2018; Akangbe et al., 2012; Obadeyi, 2015; Muthoni, 2016; Sowmyan et al., 2011; Aliu et al., 2015; Taiwo et al., 2016). It is thus expected that the application of the resources of microfinance banks will grow MSMEs in Nigeria, leading to the eradication of poverty and subsequent growth of the economy.

Studies however, revealed that this has not adequately translated into visible growth of the MSMEs in Nigeria. It is believed that with businesses shrinking, the bulk of the less privileged Nigerians have not come to understand the idea of microfinancing (Khan, 2020; Akande and Yinus, 2015; Moruf, 2013; Ede and Elikwu, 2018). These scholars also opined that microfinance services have not really reached the greater number of the target population. It is also argued that some factors still militate against entrepreneurs from patronising microfinance services, and with the snail-like growth of businesses in Nigeria, it is doubtful if microfinance has helped in reducing poverty (Khan, 2020; Akande and Yinus, 2015; Moruf, 2013; Ede and Elikwu, 2018). It is in line with these submissions that this study will also investigate the nexus between microfinance banks and the growth of MSMEs in Nigeria.

\section{Review of related literature \\ Overview of microfinance services in Nigeria}

Muthoni (2016), citing Ruben (2007), believed that group lending method, targeting of women, offering of graduated loans, and higher interest rates than the traditional banks, are the four features of microfinance. These authors argued that microfinance deals with small groups requiring loans for business growth and expansion and also uses microcredit as a tool to enhance economic development to the poor in the society. The microcredit, an important strategy in the global fight against poverty, is one of the products of microfinance institutions for impoverished people to become self-employed and selfreliant (Nawal, 2010, cited by Muthoni, 2016). Microfinance institutions, therefore, serve as a bridge builder for MSMEs in overcoming commercial, economic, and business challenges. In Nigeria, the 2012 Central Bank of Nigeria rules, and regulations for the supervision of microfinance banks, segregated the services into permissible activities and prohibited activities. The March 2020 Exposure Draft of the guidelines for the regulation and supervision of microfinance banks in Nigeria, however, changed the prohibited activities to non-permissible activities (CBN, 2020). The permissible activities in the 2012 regulatory and supervisory framework for MFBs include - the acceptance of various types of deposits including savings, time, target and demand from individuals, groups and associations, except public sector deposits (government); provision of credit to customers, including formal and informal self-help groups, individuals and associations; promoting and monitoring of loan usage among its customers by providing ancillary capacity building in areas such as record keeping and small business management; issuance of redeemable debentures to interested parties to raise funds from members of the public with approval of $\mathrm{CBN}$; collection of money or proceeds of banking instruments on behalf of its customers through correspondent banks; and buying selling and supplying industrial and agricultural inputs, livestock, machinery and industrial raw materials to poor persons on credit and to act as agent for any association for the sale of such goods or livestock.

The prohibited activities for MFBs include - non-acceptance of public sector (government) deposit except for the permissible activities; foreign exchange transactions; international commercial papers; international corporate finance; international electronic fund transfer; cheque clearing activities; dealing in land for speculative purposes; and real estate except for its use as office accommodation (CBN, 2012). The need to reposition and strengthen the MFBs towards improved performance and to complement other ongoing reform in the sector necessitated the reviewed guidelines (Amugo - CBN, 2020). Regarding the 2020 exposure draft, the reviewed guideline streamlined the contents of the permissible activities and the nonpermissible activities to encourage the focus and products' deliveries of microfinance banks for 
performance enhancement. Regarding this, Ede and Elikwu (2018) argued that the financing mechanisms of microfinance banks in Nigeria are microcredit delivery, small savings and deposit mobilisation, and micro-insurance and guarantee scheme. The scholars further opined that the roles of MFBs in the financing of SMEs in Nigeria are - serving the unbanked population; provision of microcredit facilities; SME entrepreneurial development, financial intermediation, SME employment opportunities, and financial inclusion. To enhance efficient service deliveries, these banks are not only found in the heart of the cities for aggressive marketing and marketing drive, but they are designed to be the nexus and data bank of the government and the traditional banks about the poor of both urban and rural areas (Obasi et al., 2014).

Accordingly, the features designed to differentiate microfinance banks from the traditional financial institutions are the administrative system of giving small and uncollateralised loans to people in the rural communities, with primary focus on agriculture, agro-allied activities, and small-scale businesses, among others (Obasi et al., 2014). Postulating however, Ailemen et al. (2016) argued that the key issues in microfinance include the realisation that the financial needs of the poor people are diverse like loans, savings, money transfer and insurance, which the MFBs provide. The scholars further opined that MFB is a powerful tool in the war against poverty through the building of assets and serving as an absorber to external vagaries and financial shocks. Thus, microfinance banks will enhance savings and investment opportunities through the mobilisation of local savings into productive activities; will improve income distribution of the Nigerian population; will encourage rural industrialisation, which lead to reduction in rural-urban migration; and will encourage entrepreneurship behavior among the youths, women, and the poor in becoming self-reliant (Asor et al., 2016).

Table 1: Permissible activities of MFBs: 2012 and 2020 compared

\begin{tabular}{l}
\hline 2012 Guidelines (Services) \\
\hline Acceptance of various types of deposits including \\
savings, time, target and demand deposits from \\
individuals, groups, and associations; except public \\
sector deposits (government). \\
Provision of credit to its customers, including formal \\
and informal self-help groups, individuals, and \\
associations.
\end{tabular}

\begin{tabular}{|l|l|l|l|l|l|l}
\hline N/A & Pro \\
\hline Promoton and monitoring of lon usage anong its & Pro
\end{tabular}

Promotion and monitoring of loan usage among its customers by providing ancillary capacity building in areas such as record keeping and small business management.

Issuance of redeemable debentures to interested parties to raise funds from members of the public with approval of the CBN.

2020 Guidelines - Exposure Draft (Services)

Acceptance of various types of deposits including savings, time, target and demand from individuals, groups, and associations.

Provision of credit to its customers.

Collection of money or proceeds of banking instruments on behalf of its customers through correspondent banks.

\section{$\mathrm{N} / \mathrm{A}$}

Provision of housing loans.

Provision of ancillary services such as capacity building on record keeping and small business management and safe custody.

Issuance of debentures to interested parties to raise funds from members of the public with the prior approval of the CBN.

Collection of money or proceeds of banking instruments on behalf of its customers including clearing of cheques through correspondent banks.

Act as agent for the provision of mobile banking, micro insurance and any other services as may be determined by the CBN from time to time, within the geographic coverage of its licence.

N/A Appoint agents to provide financial services on its behalf in line with the CBN Agent Banking Guidelines, within the geographic coverage of its licence.

Provision of payment services such as salary, gratuity, pension for the various tiers of government ${ }^{* * *}$.

Provision of payment services such as salary, gratuity, pension for employees of the various tiers of government.

Provision of loan disbursement services for the delivery of credit programme of government, agencies, groups, and individual for poverty alleviation on non-recourse basis ${ }^{* * *}$.

Provision of loan disbursement services for the delivery of credit programme of government, agencies, groups, and individual for poverty alleviation on non-recourse basis. 
Provision of ancillary banking services to their customers such as domestic remittance of funds and safe custody.

Maintenance and operation of various types of account with other banks in Nigeria.

Investment of surplus funds of the MFB in suitable instruments including placing such funds with correspondent banks and in Treasury Bills.

Pay and receive interests as may be agreed upon between them and their clients in accordance with existing guidelines.

Operation of micro leasing facilities, micro finance related hire-purchase and arrangement of consortium lending and supervise credit schemes to ensure access of micro finance customers to inputs for their economic activities.

Receiving of refinancing or other funds from $\mathrm{CBN}$ and other sources, private or public, on terms mutually acceptable to both the provider of the funds and the recipient MFBs.

Provision of micro finance related guarantees for their customers to enable them to have greater access to credit and other resources.

Buying, selling, and supplying industrial and agricultural inputs, livestock, machinery, and industrial raw materials to poor persons on credit and to act as agent for any association for the sale of such goods or livestock.

Investment in shares or equity of anybody corporate, the objective of which is to provide microfinance services to poor persons.

Encouragement of investment in cottage industries and income generating projects for poor persons as may be prescribed by the CBN.

Provision of services and facilities to customers to hedge various risks relating to microfinance activities.

Provision of professional advice to poor persons regarding investments in small businesses; rendering managerial, marketing, technical and administrative advice to customers and assisting them in obtaining services in such fields.

N/A

Mobilise and provide financial and technical assistance and training to micro-enterprises.

Provision of loans to microfinance clients for home improvement and customer credits.

Performance of non-banking functions that relate to micro finance related business development service such as co-operatives and group formation activities, rural industrialization and other support services needed by micro enterprises.

$\mathrm{N} / \mathrm{A}$
Provision of banking services to its customers such as domestic remittance of funds.

Maintenance and operation of various types of account with other banks in Nigeria.

Investment of its surplus funds in suitable money market instruments approved by the CBN.

\section{$\mathrm{N} / \mathrm{A}$}

Operation of micro leasing facilities, micro finance related hire purchase and arrangement of consortium lending.

Participate in $\mathrm{CBN}$ intervention Fund and funds other sources.

Provision of microfinance related guarantees for its customers.

Financing agricultural inputs, livestock, machinery, and industrial raw materials to low-income persons.

\section{$\mathrm{N} / \mathrm{A}$}

Investment in cottage industries and income generating projects for low-income persons as may be prescribed by the CBN from time to time.

\section{$\mathrm{N} / \mathrm{A}$}

Provision of professional advice to low-income persons regarding investments in small businesses.

Issuance of domestic commercial paper subject to the approval of the CBN.

Provide financial and technical assistance and training to microenterprises.

N/A

$\mathrm{N} / \mathrm{A}$

Any other permissible activity as may be approved by the CBN from time to time. 
The Nigerian government through the CBN in table 2, also revised the prohibited activities that the MFBs should not engage, both in semantics and in contents. The word "prohibited" was changed to "nonpermissible", and the 2020 exposure draft was done to include collection of third-party cheques and other instruments for the purpose of clearing through correspondent banks (cheque clearing activities under the 2012 regulations), and financing illegal activities, etc. These were done to support the development and sustainability of MFBs (Amugo - CBN, 2020).

Table 2: Prohibited (Non-Permissible) activities of MFBs: 2012 and 2020 compared

\begin{tabular}{|c|c|}
\hline 2012 Guidelines & 2020 Guidelines - Exposure Draft \\
\hline $\begin{array}{l}\text { Acceptance of public sector (government) deposit } \\
\text { except for the permissible activities } * * *(\text { see table } 1 \text { ) }\end{array}$ & $\mathrm{N} / \mathrm{A}$ \\
\hline Foreign exchange transactions. & $\begin{array}{l}\text { Foreign currency transactions, except foreign currency } \\
\text { borrowings. }\end{array}$ \\
\hline International commercial papers. & International commercial papers. \\
\hline International corporate finance. & International corporate finance. \\
\hline International electronic funds transfer. & International electronic funds transfer. \\
\hline Cheque clearing activities. & Clearing house activities. \\
\hline $\mathrm{N} / \mathrm{A}$ & $\begin{array}{l}\text { Collection of third-party cheques and other instruments } \\
\text { for the purpose of clearing through correspondent banks. }\end{array}$ \\
\hline Dealing in land for speculative purposes. & Dealing in land for speculative purposes. \\
\hline $\begin{array}{l}\text { Real estate except for its use as office } \\
\text { accommodation. }\end{array}$ & Real estate except for its use as office accommodation. \\
\hline Allow any facility for speculative purposes. & Provision of any facility for speculative purposes. \\
\hline $\begin{array}{l}\text { Enter into leasing, renting, and sale/purchase of any } \\
\text { kind with its directors, officers, employees, or } \\
\text { persons who either individually or in concert with } \\
\text { their family members and beneficiaries own five } \\
\text { percent ( } 5 \% \text { ) or more of the equity of the MFB, } \\
\text { without the prior approval in writing of the Central } \\
\text { Bank of Nigeria. }\end{array}$ & $\begin{array}{l}\text { Leasing, renting, and sale/purchase of any kind with } \\
\text { related parties and/or significant shareholders (five } \\
\text { percent or more of the equity) of the MFB, without the } \\
\text { prior written approval of the CBN. }\end{array}$ \\
\hline $\mathrm{N} / \mathrm{A}$ & Financing of any illegal activities. \\
\hline $\mathrm{N} / \mathrm{A}$ & $\begin{array}{l}\text { Any activity other than those permitted as stated above } \\
\text { or as may be prescribed by the Central Bank of Nigeria } \\
\text { from time to time. }\end{array}$ \\
\hline
\end{tabular}

Source: Tabulated from the records of CBN (2012) and CBN (2020)

\section{The impact of micro, small and medium enterprises on Nigeria's economic growth}

The high level of poverty in emerging economies like Nigeria could be seen as a reflection of its snail-like growth. According to Khan (2020), small and medium scale business is one of the widely practised venture in Nigeria but having a mirage of problems like constrained access to funding. This scholar believed that small and medium enterprises contribute to the development of the economy through output of goods and services, creation of jobs at a relatively low capital, serving as the autopilot for the minimisation of income disparities by advancing the availability of skilled and semi-skilled workers for industrial expansion, and offer excellent breeding ground for entrepreneurial and managerial talent. The Small and Medium Enterprises (SMEs), equally known as Micro, Small and Medium Enterprises (MSMEs), serves as the bedrock for the emergence of new entrepreneurs to attaining the level of established commercial enterprises. Asor et al. (2016) believed that small scale businesses contribute to employment generation, ensure income equality, improve the standard of living and rapid industrialisation, and could also foster economic and social development in Nigeria.

In contributing to the problems of MSMEs in Nigeria, Alalade et al. (2013), postulated that the capital providers are primarily averse to the financing of this sector due to the high transaction cost, low returns, and the going concern threat, which they see as highly risky. Alalade et al. (2013) believed that financing still remains the strategic resource for new ideas and for the survival of MSMEs. Despite the relevance of funding for the growth of small-scale businesses, Andabai and Jessie (2018) opined that their growth has not been significantly enhanced by the activities of microfinance banks. Examining the 
implication of the assertion of Andabai and Jessie (2018), Obadeyi (2015) argued that the problem of underdevelopment arises as a result of the reluctance of traditional banks to grant loans to the low-income earners, micro business owners and the rural people. Regarding this, the MSMEs are still underfunded and only $50 \%$ of Nigeria's poorest households have access to financial services (Obadeyi, 2015; Akande and Yinus, 2015). Moruf (2013) whilst contributing, argued that microfinance banks are competing with the traditional banks for universal banking rather than focussing on the small-scale businesses they were purposively established to undertake. Consequently, there is a need for a more effective monitoring of the activities of the microfinance banks by the relevant regulatory authorities, for better efficient service delivery. The divergent view of Bakare (2019), however, showed that Nigeria has recorded appreciable economic growth through the funding of MSMEs.

\section{Theoretical framework}

The theories in financing activities, relationship between lenders and the borrowers, as well as the financial intermediation include - Financial Constraint Theory, Pecking Order Theory, etc. Ede et al. (2018) argued that the existence of a well-functioning financial intermediation between the lender and the borrower would provide efficient allocation of resources, which will lead to the growth of other economic sectors. The relevant theories reviewed, will therefore, show the connecting link between lenders and the borrowers in relationship to economic growth.

\section{Financial Constraint Theory (FCT)}

Ede et al. (2018) opined that this theory was pioneered by Fazzari et al. (1988). Study posits that FCT tests for differences in sensitivity of investment to internal funds in businesses, having consideration for different levels of informational opacity. This it does through the splitting of a sample of enterprises into subsamples, which is defined according to the suitable theoretical antecedent that characterises constrained and unconstrained firms (Ede et al., 2018). Mansour and Chichti (2011) asserted, however, that FCT studies the effect of financial frictions on enterprises' finance. The scholars argued that this theory hinges on the theoretical underpinning that encompasses the information-driven problems of studying firm's investment under the incentive restriction(s). In their contributions, Clementi and Hopenhayn (2006) postulated that borrowing constraints have important implications for firm's growth and survival. Thus, borrowing constraints emerge as a feature of the optimal long-term lending contract, and such constraints relax as the value of the borrower's claim to future cash flows increases (Clementi and Hopenhayn, 2006). According to these scholars, the optimal contract has interesting implications for firm dynamics with the empirical evidence, as age and size increase, mean and variance of growth decrease, and firm survival increases.

\section{Pecking Order Theory (POT)}

This theory argued that the financial needs of MSMEs are met in order of hierarchy (Myers, 1984; Myers and Majluf, 1984; Lucas and McDonald, 1990; Taiwo et al., 2016; Gunarsih, 2011). The theorists believed that small businesses obtain their initial funds internally and as the financial needs increase, they resort to debt capital (Taiwo et al., 2016). Gunarsih, (2011) further opined that managers have more information about the true value of the enterprise and enterprise risk compared to outside investors. Accordingly, firms finance their activities with retained earning when feasible, if these are inadequate, then debt is used, and it is only in extreme cases will firms use new equity finance (Myers, 1984, cited by Gunarsih, 2011). Thus, pecking order theory predicts that the issuance of equity (common stock) is the last alternative sources of funding, which means that firms turn to debt funds under pressure of an internal fund's shortage (Gunarsih, 2011). This study is thus anchored on the pecking order theory.

\section{Empirical Review}

Literature abounds on the relationship between microfinance institutions and micro, small and medium enterprises, especially on funding of the latter. Scholars have also researched on the impact of MSMEs on developmental activities of emerging economies like Nigeria with mixed findings. For instance, Taiwo et al. (2016) explored the roles of microfinance banks and institutions on small and medium enterprises and the extent to which the small businesses have benefitted from the credit scheme of the former. The study adopted primary data through interviews conducted on 15 small businesses 
across Lagos State, Nigeria. The study revealed that small businesses have not been given the deserved and adequate recognition that corresponds with the intensity of their contributions to economic development. The study also shows that microfinancing has a huge potential for increasing the performance of small businesses through frequent contributions in microfinancing and provision of nonfinancial services. Obadeyi (2015) examined the relationship between microfinance banking and the development of small business in Nigeria. The study adopted primary data through questionnaire and oral interview on 80 respondents with 70 effectively responded. The study established that microfinance banks have the capacity to boost economic growth in Nigeria. Asor et al. (2016) examined the impact of microfinance banks on small scale businesses in Calabar, Cross Rivers State, Nigeria. The study adopted descriptive research method on both small-scale businesses and microfinance banks. The findings revealed increased challenges of microfinance operations and the challenges of small-scale businesses. The results also show that microfinance banks have a significant impact on the growth of small and medium businesses.

In the investigation of the contributions of microfinance banks to the development of small and medium scale enterprises in Damaturu, Yobe State, Nigeria, Khan (2020) administered questionnaire to 50 respondents with 41 respondents correctly filled and returned. The study analysed data through chisquare tool to test the hypotheses. The findings revealed that strict borrowing conditions militate against the efforts of entrepreneurs from patronising the banks. Bakare (2019) investigated the nexus between microfinance credit and small and medium business growth in Nigeria from 2006-2014. The results from panel data analysis revealed that bank credit has negative and a statistically insignificant relationship with business growth in Nigeria. Ailemen et al. (2016) examined the roles of microfinance towards the dispersion of credit among the working poor and the standard of living. Field survey was adopted with data analysed through descriptive and inferential statistics. The findings from the analysis of the crosssectional data revealed that microfinance banks in Nigeria are tailored after the Grameen Bank, with focus on the poor. Akande and Yinus (2015) assessed the role of microfinance banks on the development of small and medium scale enterprises in Nigeria. Primary and secondary data were used for the study. The instruments for primary data was questionnaire administered one hundred two (120) questionnaires to registered SMEs in Lagos State, with one hundred and four (104) found useful. The results revealed that a considerable number of people that patronise microfinance banks have the knowledge. The findings also showed that microfinance banks have positive influence on entrepreneurial development.

Akingunola et al. (2018) investigated the impact of microfinance banks on micro and small enterprises in Ogun State, Nigeria. Survey design method was used with the administration of 408 questionnaires on micro-enterprises. The findings revealed a negative nexus between intermediary financial services and small-scale businesses. The results also showed a positive relationship between microcredit and business expansion. Alalade et al. (2013) examined the relationship and causality between microfinance bank operations and entrepreneurship development in Ogun State. The study adopted survey research design with data collected through financial statements and questionnaire. The findings revealed that there is no significant difference between entrepreneurs that use microfinance banks in terms of loans and advances and those that did not. It was also revealed that the inability of the SMEs entrepreneurs to provide the collateral assets prevented them from assessing the required loans from microfinance banks. Moruf (2013) evaluated the convenience at obtaining credit, adequacy of the credit supplied relative to demand, among others from microfinance banks and the extent at which SMES have benefitted. The study which was conducted on SMEs in Osun State, Nigeria, administered questionnaire on SMEs in addition to their financial statements. The results showed a positive and significant relationship between microcredit delivery service of microfinance banks and the performance of SMEs.

Despite these studies, there is still a wide gap to fill as to the extent at which microfinance banks applied their resources for the use of micro, small and medium enterprises in Nigeria. The most recent development on the nexus between microfinance banks and MSMEs as to the contemporary challenges faced by these low-income entrepreneurs in business sustainability is also a gap to fill. Thus, this study aims at proffering empirical solutions to these. 


\section{Methodology}

Primary data through survey research design was used. Self-administered questionnaires were adopted to obtain the relevant data for the study. The targeted population and the sample size were 250 microfinance operators and micro, small and medium entrepreneurs in Lagos State, Nigeria, with 223 $(89.2 \%)$ respondents validly returned their copies. The study chose Lagos State because it is the commercial hub of Nigeria and having the highest concentration of entrepreneurs and microfinance operators in Nigeria. Logit regression method was used to analyse data.

\section{Model specification:}

Microfinance Banks Services (MFBs) is the independent variable and proxied by Small Scale Financial Services (SSFS); Financial Sustainability (FST); Absence of Assets-based Collateral (AAC); and Advisory Services (ADS).

Growth of Micro, Small and Medium Enterprises (GMSME) is the dependent variable. Meanwhile, two hypotheses were formed and tested by the study.

\section{The model is expressed as follows:}

Growth of Micro, Small and Medium Enterprises (GMSME) $=\mathrm{f}$ (Small Scale Financial Services (SSFS); Financial Sustainability (FST); Absence of Assets-based Collateral (AAC); Advisory Services (ADS)

$$
\begin{aligned}
& \mathrm{GMSME}=\mathrm{f}(\mathrm{SSFS}, \mathrm{FST}, \mathrm{AAC}, \mathrm{ADS}) \ldots \ldots \ldots \ldots \ldots \ldots \ldots \ldots \ldots \ldots \\
& \mathrm{GMSME}=\mathrm{f}\left(\beta_{\mathrm{o}}+\beta_{1} \mathrm{SSFS}+\beta_{2} \text { FST }+\beta_{3} \mathrm{AAC}+\beta_{4} \text { ADS }+\mu\right)
\end{aligned}
$$

\section{Data presentation, analysis, and discussion of findings}

\section{Test of Hypothesis}

This study tested two hypotheses. The hypotheses stated in null form are:

Microfinance banks have not significantly channelled their resources toward micro, small, and medium enterprises.

There is no significant positive relationship between microfinance banks and micro, small and medium enterprises.

\section{Hypothesis 1}

Microfinance banks have not significantly channelled their resources toward micro, small, and medium.

The coefficient in table 3 revealed that the $t$-calculated of 8.181 is greater than $t$-tabulated of 0.000 at $5 \%$ level of significance. Consequently, the decision rule is that if the $t$-calculated $<t$-tabulated, then the null hypothesis should be rejected by accepting the alternate hypothesis. It can then be concluded that microfinance banks have significantly channelled their resources toward the expected target (MSME).

\begin{tabular}{|c|c|c|c|c|c|c|}
\hline \multirow[b]{2}{*}{ Model } & & \multicolumn{2}{|c|}{ Unstandardized Coefficients } & \multirow{2}{*}{$\begin{array}{l}\text { Standardized Coefficients } \\
\text { Beta }\end{array}$} & \multirow[b]{2}{*}{$\mathrm{T}$} & \multirow[b]{2}{*}{ Sig. } \\
\hline & & $\mathrm{B}$ & Std. Error & & & \\
\hline 1 & (Constant) & 2.779 & .340 & & 8.181 & .000 \\
\hline & $\begin{array}{l}\text { Expected } \\
\text { Target (ET) }\end{array}$ & .387 & .071 & .343 & 5.437 & .000 \\
\hline
\end{tabular}

Table 3: Coefficients

Dependent Variable: Fund of Micro Finance Banks (FMFBs)

Source: Author's field work (2020)

\section{Hypothesis 2}

There is no significant positive relationship between microfinance banks and micro, small and medium enterprises.

Model estimation from the statistical output:

GMSME $=3.510+0.115$ SSFS $+0.045 \mathrm{FST}+0.055 \mathrm{AAC}+0.033 \mathrm{ADS}$.

The a priori expectation $-\beta_{o}>0, \beta_{1-4}>0$, is thus met.

The result of the regression analysis showed how much of the variation in the dependent variable is explained by the variation of the components in the independent variable. The decision rule is that the null hypothesis should be rejected if the $t$-calculated is greater than the $t$-tabulated and vice versa. In the multiple regression analysis results, $t$-calculated of 6.540 is greater than $t$-tabulated of 0.000 at $5 \%$ level of significance, which indicates that the null hypothesis is rejected and accepting the alternate hypothesis. 
Thus, there is significant positive relationship between microfinance banks and growth of micro, small, and medium enterprises in Nigeria. This result is also affirmed from the level of significance of the components of the independent variables of $0.000,0.087,0.528,0.358$ and 0.616 which are less than $5 \%$ acceptable level of significance. The result also shows that there is positive relationship between Small Scale Financial Services (SSFS) and Growth of Micro, Small, and Medium Enterprises (GMSME) since $\beta S S F S$ (0.115) is positive, indicating that Small Scale Financial Services (SSFS) of microfinance banks will lead to the Growth of Micro, Small, and Medium Enterprises (GMSME). It also shows that there is positive relationship between Financial Sustainability (FST) and Growth of Micro, Small, and Medium Enterprises (GMSME) since $\beta$ FST (0.045) is positive, which means that through Financial Sustainability (FST) programs of microfinance banks, there will be Growth of Micro, Small, and Medium Enterprises (GMSME). The result also shows that there is positive relationship between Absence of Assets-based Collateral (AAC) and Growth of Micro, Small, and Medium Enterprises (GMSME) since $\beta A A C$ (0.055) is positive. This means that the Absence of Assets-based Collateral (AAC) will increase the access to loans and lead to the Growth of Micro, Small, and Medium Enterprises (GMSME). The result also shows that there is positive relationship between Advisory Services (ADS) and Growth of Micro, Small, and Medium Enterprises (GMSME) since $\beta A A C(0.033)$ is positive. This means that the Advisory Services (ADS) of microfinance banks will result in the Growth of Micro, Small, and Medium Enterprises (GMSME).

Table 4 shows that $\mathrm{R}$ was 0.155 . This implies that there is a positive nexus between the components of the independent variables and dependent variable. The coefficient of determination $\mathrm{R}^{2}$ was 0.024 . This indicates that $2.40 \%$ of growth of micro, small and medium enterprises in Nigeria, could be explained by microfinance banks services, while the remaining $97.6 \%$ could be as a result of other variables not accounted for in this model. Table 6 also shows that relationship between MFBs and GMSME is statistically significant $(\mathrm{P}=.000<.05)$ with $\mathrm{t}$-statistics $=6.540$. The adjusted $\mathrm{R}^{2}(0.006)$, which is closer to the $\mathrm{R}^{2}$ (0.024). This implies that the model is fit for making generalization. Thus, microfinance banks services, proxied by SSFS, FST, AAC, and ADS have significant positive effect on the growth of micro, small and medium enterprises in Nigeria.

\begin{tabular}{|c|c|c|c|c|}
\hline Model & $\mathrm{R}$ & R Square & $\begin{array}{l}\text { Adjusted } \\
\text { Square }\end{array}$ & $\begin{array}{l}\text { RStd. Error of the } \\
\text { Estimate }\end{array}$ \\
\hline 1 & $.155^{a}$ & .024 & .006 & .54400 \\
\hline
\end{tabular}

a. Predictors: (Constant), SSFS, FST, AAC, ADS

Source: Author's field work (2020)

Table 5: ANOVA $^{\mathrm{a}}$

\begin{tabular}{|ll|l|l|l|l|l|}
\hline Model & & Sum of Squares & df & Mean Square & F & Sig. \\
\hline 1 & Regression & 1.594 & 4 & .398 & 1.346 & $.254^{\mathrm{b}}$ \\
& Residual & 64.514 & 218 & .296 & & \\
Total & 66.108 & 222 & & & \\
\hline
\end{tabular}

a. Dependent Variable: GMSME

b. Predictors: (Constant), SSFS, FST, AAC, ADS

Source: Author's field work (2020)

Table 6: Coefficients

\begin{tabular}{|c|c|c|c|c|c|c|}
\hline \multirow[b]{2}{*}{ Model } & & \multicolumn{2}{|c|}{ Unstandardized Coefficients } & \multirow{2}{*}{$\begin{array}{l}\text { Standardized Coefficients } \\
\text { Beta }\end{array}$} & \multirow{2}{*}{$\mathrm{T}$} & \multirow[b]{2}{*}{ Sig. } \\
\hline & & $\mathrm{B}$ & Std. Error & & & \\
\hline \multirow[t]{5}{*}{1} & (Constant) & 3.510 & .537 & & 6.540 & .000 \\
\hline & SSFS & .115 & .067 & .119 & 1.722 & .087 \\
\hline & FST & .045 & .071 & .044 & .632 & .528 \\
\hline & AAC & .055 & .059 & .063 & .921 & .358 \\
\hline & ADS & .033 & .066 & .035 & .502 & .616 \\
\hline
\end{tabular}

a. Dependent Variable: GMSME

Source: Author's field work 


\section{Policy implications and recommendations \\ Conclusion}

To actualise the developmental programs of government, especially in emerging economies like Nigeria, effective funding of micro, small and medium enterprises is imperative. Despite the importance of this sector in national development, studies have shown that funding is a major obstacle to its growth (Khan, 2020; Akingunola et al., 2018; Alalade et al., 2013). To address this lacuna, government established microfinance banks to fund the MSMEs. According to scholars, this has not effectively translated to expected growth for this sector (Khan, 2020; Akande and Yinus, 2015; Moruf, 2013; Ede and Elikwu, 2018). This has elicited concern from the stakeholders in ascertaining if the resources of microfinance banks have really been channelled toward the expected target and to empirically ascertain if there is any nexus between microfinance banks and MSMEs in Nigeria, the main objective of this study. Previous studies, however, have examined the impact of MFBs on small enterprises, most especially on entrepreneurial development (Bakare, 2019; Akingunola et al, 2018; Obadeyi, 2015; Akande and Yinus, 2015). These have been achieved without extensive investigation on allocation of resources to MSMEs. This study thus brought to fore from the perception of MFBs operators, how the resources were channelled to the MSMEs. The study is also in agreement with Sussan and Obamuyi (2018), Asor et al. (2016), Akande and Yinus, (2015), and Akingunola et al (2018), but in contrast with the studies of Alalade et al (2013), Obasi et al (2014), and Bakare (2019), on the relationship between the independent and dependent variables. The findings, however, showed that the resources have been channeled to the expected target (MSMEs) by the rejection of the null hypothesis. The results also revealed a positive significant nexus between microfinance banks and the growth of micro, small and medium enterprises in Nigeria. This means that any increase in the deployment of microfinance banks services as represented by Small Scale Financial Services (SSFS); Financial Sustainability (FST); Absence of Assets-based Collateral (AAC); and Advisory Services (ADS) toward MSMEs will translate to growth in the industry. Thus, MFBs is positively linked to GMSME.

\section{Recommendations}

In consideration of the findings of this study, it is recommended that:

1. A strong and more effective team comprises of all stakeholders should be put in place by the government to ensure that the microfinance banks do not derail from their primary responsibility of sustaining funding for the MSMEs.

2. Central Bank of Nigeria $(\mathrm{CBN})$ should be more proactive to address any area of infractions by microfinance banks for a more efficient management.

3. Timely statutory audit of microfinance banks should be procedurally addressed to guide against accumulation of internal control weaknesses, most especially as it concerns granting of credits to MSMEs.

4. There should be effective management and monitoring of the MSMEs to ensure that the facilities granted are utilised as intended.

5. Government should do a more effective profiling of MSMEs in the country so as to have the true picture of the needs for better economic development of the country.

\section{Limitations of the study}

The social distancing in Nigeria as a result of the Covid-19 pandemic could not enable the authorities in charge of the association of microfinance banks in Lagos to respond to the request for its membership. This, if obtained, could have been used to determine a more scientific sample size. The study could equally have included other big cities like Portharcourt, Kano, Onitsha, and Ilorin from other zones in Nigeria in the population, to a get a more representation of microfinance banks and MSMEs in Nigeria.

\section{Areas for further research}

Regarding the impact of the Covid-19 pandemic on business activities and the relative inflation in Nigerian economy, further studies could examine the impact that this would have on the disbursement pattern of MFBs resources to MSMEs. Further research could also adopt secondary data from the records of the MFBs, to ascertain how the resources allocated to MSMEs, affect economic growth, using time series and/or cross-sectional data analysis methods. 


\section{References}

Abubakar, L. S., Zainol, F. A. \& Abdullahi, M. S. (2015). Lingering challenges of Microfinance Institutions (MFIs) and the way forward. International Journal of Academic Research in Economics and Management, 4(3), 31-37. Doi: 10.6007/IJAREMS/v4-i3/1815

Ailemen, I. O., Asaolu, J. N. \& Areghna, I. (2016). Microfinance and poverty alleviation in South West Nigeria: Empirical Evidence. Journal of South African Business Research, 2016(2016), 1-19.

Akande, O. O. \& Yinus, O. (2015). An assessment of micro finance banks impact on

entrepreneurship development in Nigeria. International Journal of Advances in Management and Economics, 4(3), 148-154.

Akingunola, R. O., Olowofela, E. O. \& Yunusa, L. (2018). Impact of microfinance banks on micro and small enterprises in Ogun State, Nigeria. Binus Business Review, 9(2), 163-169.

Alalade, Y. S., Amusa, B. O. \& Adekunle, O. A. (2013). Microfinance bank as a catalyst for entrepreneurship development in Nigeria: Evidence from Ogun State. International Journal of Business and Social Science, 4(12), 286-303.

Aliu, N. A., Gakure, R. W. \& Orwa, G. (2015). Effects of Microfinance Bank's (MFBs) customer relationship management on services to Small and Medium Enterprises (SMEs) in Nigeria. International Journal of Advanced Studies in Business Strategies and Management, 3(1), 99-108.

Amugo, K. (2020). Exposure draft of the guidelines for the regulation and supervision of

microfinance banks in Nigeria. Central Bank of Nigeria, FPR/DIR/GEN/CIR/07/048. www.cbn.gov.ng

Andabai, P. W. \& Jessie, I. C. (2018). Microfinance banks' credit and the growth of Small and Medium Scale Businesses (SMBS) in Nigeria (1990-2016): Investigating the nexus. Journal of Economics and Sustainable Development, 9(6), 28-33.

Asor, A. E., Essien, M. E. \& Ndiyo, N. (2016). The impact of microfinance banks on small

scale businesses in Cross River State: A case study of Calabar Metropolis. International Journal of Innovative Finance and Economics Research, 4(1), 25-31.

Bakare, M. A. (2019). Microfinance credits and growth of business firms in Nigeria. International Journal of Innovation and Research in Educational Sciences, 6(6), 782-790.

Central Bank of Nigeria (2012). Regulatory and supervisory framework for Microfinance Banks (MFBs) in Nigeria. www.cbn.gov.ng

Clementi, G., \& Hopenhayn, H. (2006). A Theory of Financing Constraints and Firm

Dynamics. The Quarterly Journal of Economics, 121(1), 229-265. Retrieved September 17, 2020, from http://www.jstor.org/stable/25098789

Dutse, A. Y., Ningi, S. I. \& Abubakar, S. (2013). Technopreneurship and enterprise growth in

Nigeria: An exploration into the latent role microfinance banks. IOSR Journal of Business and Management (IOSR-JBM), 12(2), 25-32.

Ede, U. S. \& Elikwu, M. I. (2018). Specialised institutions (microfinance banks) and business

revolution in Nigeria. A paper presented at the $7^{\text {th }}$ International Social and Management Science Research Conference, Kaduna State University, $9^{\text {th }}-10^{\text {th }}$ May 2018.

Fazzari, S., Hubbard, R. G. \& Petersen, B. (1988). Financing constraints, corporate investment, and Q. Brooking Papers on Economic Activity, 1, 41-195.

Haider, S. H., Asad, M. \& Fatima, M. (2018). Microfinance and performance of micro and

small enterprises: Does training has an impact? European Centre for Research Training and Development, 6(4), 40-49.

Khan, B. (2020). Microfinance banks and its impact on small and medium scale enterprises in Nigeria. World Scientific News, 141, 151-131.

Lucas, D. \& McDonald, dan R.L. (1990). Equity issues and stock price dynamics. Journal of Finance, 45, 1019-1043.

Mansour, W. \& Chichti, J. E. (2011). Financing constraints theory: A narrative approach. $6^{\text {th }}$

International Finance Conference on Financial Crisis and Governance, Cambridge Scholars Publishing, 465-490. https://www.researchgate.net/publication/327860222_Financing_constraints_theory_a_narrative_approach

Moruf, O. (2013). Evaluation of the Nigerian microfinance banks credit administration on

small and medium scale enterprises operations. International Review of Management and Business Research, 2(2), 505-517.

Muthoni, M. P. (2016). Assessing institutional characteristics on microcredit default in

Kenya: A comparative analysis of microfinance institutions and financial intermediaries. Journal of Education and Practice, 7(18), 178-198.

Myers, S. C. (1984). The Capital Structure Puzzle. The Journal of Finance, 39, 575-592.

Myers, S. C. \& Majluf, dan N. S. (1984). Corporate financing and investment decisions

when firms have information that investors do not have. Journal of Financial Economics, 13, 187-221.

Obadeyi, J. A. (2015). Microfinance banking and development of small business in emerging

economy: Nigerian Approach. IOSR Journal of Economics and Finance (IOSR-JEF), 6(2:1), 50-60. Doi: 10.9790/593306215060 . 
Obasi, N. J., Chukwuka, O. I. \& Akwawa, U. A. (2014). Impact of microfinance lending on economic growth of third world nations: Study of Nigeria. International Journal of Business, Economics and Management, 1(8), 201-215.

Ruben, M. (2007). The promise of microfinance for poverty relief in the developing world. Proquest CSALLC, Discovery Guides.

Sowmyan, J., Sakthi, G. \& Praveen, K. S. (2011). Research study about the role of

microfinance institutions in the development of entrepreneurs. International Journal of Trade, Economics and Finance, 2(4), 300-303.

Sussan, M. U. \& Obamuyi, T. (2018). The impact of microfinance banks on entrepreneurship

development in Nigeria. Journal of Business and Economic Development, 3(2), 51-61. Doi: 10.11648/j.jbed.20180302.13

Taiwo, J. N., Onasanya, A. Y., Agwu, M. E. \& Benson, K. N. (2016). The role of

microfinance institutions in financing small businesses. Journal of Internet Banking and Commerce, 21(1), 1-20.

Tri Gunarsih, M. M. (2011). Pecking order theory of capital structure and governing

mechanism: Evidence from Indonesian Stock Exchange. Proceedings of the $36^{\text {th }}$ Federation of ASEAN Economic Associations (FAEA) Conference.

https://www.researchgate.net/publication/313476411_pecking_order_theory_of_capital_structure_and_governing_ mechanism_evidence_from_indonesian_stock_exchange/link/589bd544458515e5f45499d2/download 